\title{
Soil and Eco-Economic Substantiation of the Need for Switching to the Adaptive-Landscape Systems of Agriculture in the Krasnodar Krai
}

\author{
Galina Nikolayevna Barsukova ${ }^{1 *}$, Yuriy losifovich Bershitskiy', \\ Valery Petrovich Vlasenko', Alexey Alexandrovich Bagmut', \\ Alexander Zakirovich Rysmyatov' \\ ${ }^{1}$ Kuban State Agrarian University, Kalinina Street, 13, Krasnodar, 350044, Russia \\ * Corresponding author's e-mail: barsukova.g.n@mail.ru
}

\begin{abstract}
The climatic, soil, ecological and economic features of the natural landscapes in the Krasnodar Krai were analyzed. The land structure of cultivated land in Western Ciscaucasia was given; the current state of soils in the Krasnodar Krai was analyzed. The changes in the content of humus in the arable layer over the century were considered. The qualitative state of agricultural lands, such as the susceptibility to erosion, the content of humus, and indicators of the nutrients balance in the soil was shown. A conclusion the existing zonal agriculture systems do not use the landscape diversity of the region was drawn. The need for switching to the adaptive landscape system of agriculture was substantiated. Using the GIS technologies, the boundaries of the natural landscapes in the Krasnodar Krai and the areas of agricultural land was determined by types and the degree of the manifestation of erosion processes. An eco-economic assessment of the field crop rotations adapted to the natural landscape by cultivated lands was made.
\end{abstract}

Keywords: farming systems, soil erosion, humus, fertility, terrain, cropping pattern, crop rotation, eco-economic efficiency.

\section{INTRODUCTION}

The Krasnodar Krai takes a leading position in the food complex of Russia. The black soil, which occupies over $60 \%$ of the Krasnodar Krai territory, has some unique properties, the most important of which is high buffer capacity, i.e., the ability to resist the changes of the properties, which is the prerequisite for a stable operation of cultivated lands. However, as a result of the intensive exposure to the anthropogenic factors, cultivated lands turned out to be very sensitive to the external influences (natural prerequisites and the anthropogenic factors), which resulted in the disbalance of the landscape systems. At the same time, the chain reaction mechanism started working at an increasing rate, when the causes and consequences of changes swap places. This applies to the emergence and the dynamics of hydromorphic complexes in the initially automorphic soils. The lands with eroded soils among the non-eroded analogs, on the contrary, are permanent, but their dynamics tend to increase the size and severity of erosion. The main negative processes in the region are wind and water soil erosion, occurring in the area of 2,364.3 thousand ha of agricultural lands, and occupying $31.3 \%$ of the agricultural land.

According to the data of the Kuban State Scientific Research and Design and Survey Institute of Land Amelioration (KubanNIIgiprozem), water erosion currently affects $1,174.3$ thousand ha of arable land and the speed of the process increases. Over 35 years (1975 to 2010), the area of medium-eroded arable land had increased 3.5 times, from 45 to 159 thousand ha. Erosion (by water and wind) decreases the content of humus, reduces the thickness of 
the humus horizons, humus reserves, and, ultimately, reduces the soil fertility. This process is quick and irreversible, and cannot be eliminated by the currently used agronomic or land amelioration measures.

The humus and nutrients reserves are rapidly declining. Some researchers (Vasilko, Marchenko, Vlasenko, Terpelets) noted the long period of the build-up of negative changes in the indicators of soil fertility - the loss of humus and reduction of the humus layer thickness, loss of the most important nutrients, the black soils plow-out degree [Agroecological monitoring in the agriculture of the Krasnodar Krai, 1997; Marchenko et al., 2008; Vlasenko, Terpelets, 2012; Vlasenko, Achkanov, 2014; Zhukov, Sheujen, 2017; Serdyuchenko et al., 2018; Garkovenko et al., 2018].

According to the most preliminary calculations, only due to the lost product, the annual damage from the degradation processes in the soil in the region over the period between 1978 and 2016 amounted to 2.44 billion rubles from water saturation and waterlogging, and 6.00 billion rubles from erosion. Besides, there is damage from soil salinization, alkalinization, and chemical pollution, as well as from disturbance of the fertile layer.

Currently, virtually no measures to restore soil fertility are taken at agricultural enterprises, regardless of their form of ownership, due to the insufficient financial resources. Modern agricultural producers are interested in maximizing the profits with the intensive use of agricultural lands, which significantly increases the anthropogenic load rate, which characterizes the human impact on the state of the environment.

Taking measures on for reducing the coefficient of anthropogenic load the territory of an agricultural enterprise (creating micronurseries, forest bands, resting gills bottoms, less intensive use of the intensively used lands) is disadvantageous for the landowner or the tenant [Barsukova et al., 2015; Barsukova, Derevenetz, 2016; Barsukova et al., 2015; Nechaev et al., 2016; Koba et al., 2018; Tuzov et al., 2018; Skvortsova et al., 2018].

Currently, the adoption of the zonal principle of farming cannot ensure natural landscape restoration in the process of their agricultural use. This necessitates the transition from the zonal to the adaptive organization of the territory at each agricultural enterprise, based on the development of eco-landscape farming systems differentiated by the natural and cultivated lands.

\section{METHODS}

The methodological rationale for the practical work is the Agroecological Assessment of Lands, Development of Adaptive Landscape Systems for Agriculture and Agricultural Technologies methodological guide developed in 2005 [Kiryushin, 2005; Zverzhanovskiy et al., 2017; Koshchaev et al., 2018].

Following the methodological guide, the authors have formulated the following tasks of the research, which will be resolved using the modern geographic information technologies (GIS):

- defining the boundaries of natural and agricultural lands in the region;

- within natural landscapes, defining the area of the lands subjected to the degradation processes; and

- defining the type and the degree of degradation processes within the boundaries of the natural and cultivated lands.

The cultivated land zoning requires a comprehensive field survey, studying the materials of soil and geobotanical surveys, determining the type and extent of soil erosion, and terrain analysis.

The research included the analysis of the archival materials, the topographic material from various years at various scales, the aerial photos and space survey materials, and the materials from four rounds of soil survey. The field fixed-route soil studies were performed with the comparative study of the terrain. The monitoring using the method of fixed-route survey was performed within the Kuban-Azov plain (Vyselkovsky, Leningradsky, Kushchevsky, Eysky, and Timashevsky districts of the Krasnodar Krai).

\section{DISCUSSION}

\section{Terrain changes}

The formation of elongated windborne hillocks along the forest belts, which were meter high (or higher) was revealed. Such hillocks were shown along or within forest belts on the 1:10000 scale topographic maps (Figure 1).

Linear hillocks are windborne and constitute the result of the deposition of fine earth that was displaced by the wind from the fields. The hillocks are discontinuous, their presence and height are associated with the nature of the terrain that determines the wind speed in the surface layer. 


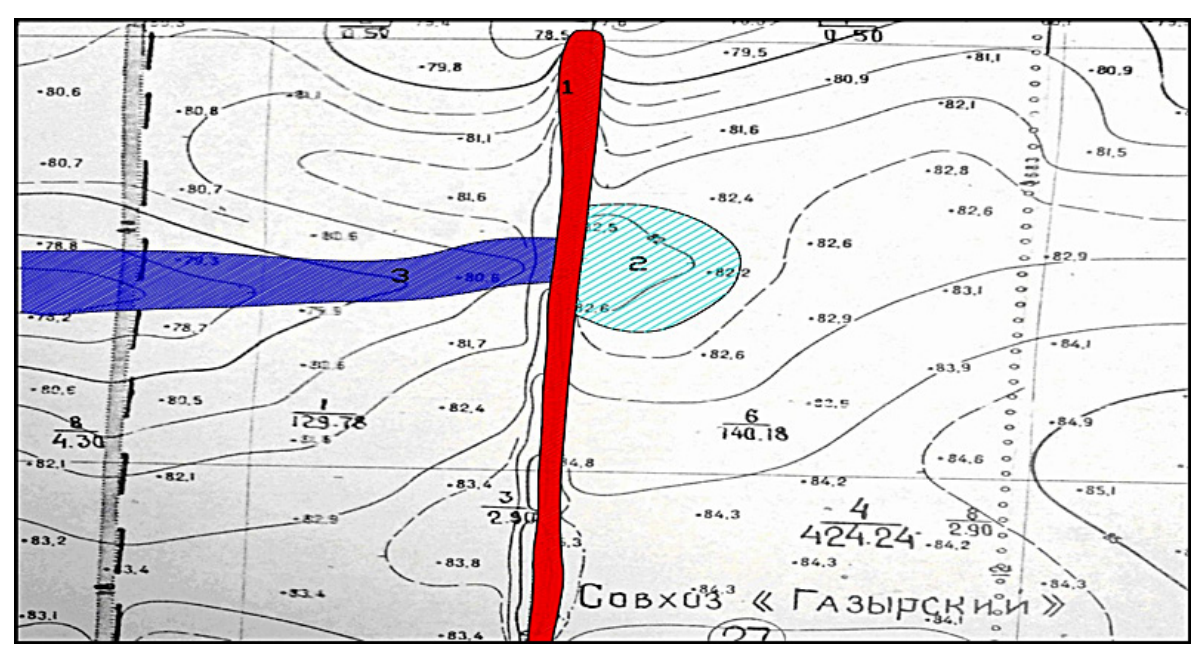

Figure 1. Windborne hillocks in the forest shelterbelts

$(1$ - red) block the gill drain $(3$ - blue) and contribute to the development of local water saturation in the adjacent fields $(2$ - blue)

These are watersheds with high wind speed; the gills are gullies that concentrate the airflows in their beds. When such places intersect with the forest belt, fine earth is deposited in it or nearby in larger amounts than in the rest of the area.

Identification of the hillock formation pattern of depending on the elements of the terrain requires a special study under specific conditions and would be the scientific basis for improving the network of forest belts. The existing network of forest belts with $500 \mathrm{~m}$ and greater distance between them does not ensure reliable protection from the wind for the arable lands.

While studying the dynamics of secluded depressions development it was shown that there is a tendency to increase the areas with such forms of mesorelief.

Studying archival materials, topographic maps from various years of the survey, and field studies at two landfills allowed drawing the following conclusions: the existence of "saucer"-shaped secluded depressions in the steppe had been earlier noted by V.V. Dokuchaev [Achkanov, Vasilko, 2006]. In the Kuban-Azov plain, secluded depressions were formed in the process of surface shaping in the Holocene as a result of the Azov Sea coastline retreating to the West and filling in the bare bottom with loess-like sediments. Such depressions are reflections of the bottom of the ancient sea. They form chains from North to South which are tens or more kilometers long. Besides, there are many "saucers" randomly scattered in the arable land that appeared in the second half of the 20th century, as evidenced by old residents, cartographic materials, and field surveys.
Under the conditions of the Western Ciscaucasia, the main purpose of the forest belts is reducing the speed of east winds that cause the wind erosion of the soil, especially in late winter and early spring (February - March). For this purpose, the shelterbelts are oriented in the meridional direction (from North to South). The main direction of the gill-river runoff in this territory is the latitudinal one (from East to West) from the spurs of the Stavropol Upland to the Azov Sea. At the same time, the forest belts intersect the gill system, and the hillocks formed along them block the gill runoff, contributing to the development of local water saturation in the adjacent fields (Figure 1).

\section{The state and structure of the agricultural land}

Natural landscapes are stable formations due to such functional properties as self-healing, selfregulation, and self-stabilization. Such functions are the result of a complex interaction between the components of the landscape (terrain, climate, hydrological and geochemical situation, vegetation, fauna, etc.).

The analysis of the state of land under the conditions of lowland steppes shows that virtually no undisturbed natural areas have remained, and all the natural lands have been converted to agricultural lands (Table 1).

For instance, in the lowland steppe arid lands, the share of agricultural lands ranges from $78 \%$ to $85 \%$ of the total area, and the remaining area is occupied by settlements, the road network, and 
Table 1. The land structure of the main cultivated lands of the Western Ciscaucasia (the average data of statistical reports by administrative regions)

\begin{tabular}{|c|c|c|c|c|c|c|c|}
\hline \multirow{3}{*}{ Cultivated lands } & \multicolumn{5}{|c|}{ The share of land, $\%$ of the total area } & \multirow{3}{*}{$\begin{array}{c}\text { The lands } \\
\text { of the } \\
\text { forest fund }\end{array}$} & \multirow{3}{*}{$\begin{array}{l}\text { Residential } \\
\text { and industrial } \\
\text { territories }\end{array}$} \\
\hline & \multicolumn{5}{|c|}{ agricultural lands } & & \\
\hline & arable land & $\begin{array}{l}\text { perennial } \\
\text { plantings }\end{array}$ & hayfields & pastures & total & & \\
\hline $\begin{array}{l}\text { Lowland steppe dry } \\
\text { agronomic }\end{array}$ & 77.0 & 0.9 & 1.5 & 3.2 & 82.6 & 0.3 & 17.1 \\
\hline $\begin{array}{l}\text { Lowland steppe } \\
\text { agronomic with insufficient } \\
\text { humidification }\end{array}$ & 79.0 & 1.0 & None & 2.2 & 82.2 & 0.1 & 17.7 \\
\hline $\begin{array}{l}\text { Lowland-depression } \\
\text { meadow-steppe agronomic } \\
\text { with unstable humidification }\end{array}$ & 66.2 & 2.5 & None & 8.9 & 77.6 & 0.05 & 22.4 \\
\hline $\begin{array}{l}\text { Piedmont forest-steppe } \\
\text { agronomic with sufficient } \\
\text { humidification }\end{array}$ & 39.1 & 3.5 & 3.2 & 20.0 & 65.8 & 13.4 & 20.8 \\
\hline
\end{tabular}

industrial sites. The lands of the forest fund occupy $0.2-0.4 \%$ of the territory, and there are no protected natural objects. From the farmland area, arable lands occupy $77 \%$, i.e., the main part of the lands has been plowed with the destruction of the natural vegetation. The same tendency is observed in the lowland steppe lands with unstable humidification.

In the meadow-steppe lowland-depression landscape, the degree of plowed land is somewhat lower $(60-70 \%)$, and the area of all farmlands varies between 75 and $80 \%$. The slight decrease in the share of agricultural lands is explained by the greater population of these places and the development of the road network $-21 \%$.

In the foothill landscape, due to the naturally high sectioning of the surface, the share of arable lands is much smaller; the non-arable lands are used as hayfields and pastures. Forests occupy a significant area. The analysis of the archival materials about the history of Western Ciscaucasia development showed that it had not been chaotic. Resettlement of the Black Sea Cossacks and the inhabitants of central Russia had been preceded by a fixed-route survey, based on which the locations for the immigrants were determined with the allocation of lands for agricultural use [Achkanov, Vasilko, 2006; Koshchaev et al., 2017; Saleeva1 et al., 2018; Kryukov et al., 2018; Koshchaev et al., 2018; Troshin et al., 2018].

In the 20th century, all suitable lands were plowed and only natural forest and shrubs along the steppe rivers and natural depressions remained intact. At the end of the $1950 \mathrm{~s}$, most forests and shrubs were uprooted in the region; only the local names remind of their existence: Ternovka, Kruglik, etc.
The destruction of forests, shrubs, and meadows contributed to the expansion of the areas of secluded depressions, as they lost the natural "pumps" that had regulated the water conditions.

\section{The state of soil fertility}

The analysis of the data obtained after many years of studies at the Kubangiprozem Institute showed that throughout the observation, the areas of the farmlands exposed to deflation had increased 1.2 times, same as the area of weakly and medium-eroded lands in the foothill cultivated lands.

Due to the increased number of secluded depressions, the land areas with signs of hydromorphic degradation of chernozems in the steppes increased - from 110 thousand ha in 1985 to 198.6 thousand ha in the 1990s. The density of the soil in the arable lands increased considerably, and the humus content in it decreased (Table 2).

Currently, it is impossible to find truly virgin plots; therefore, the humus content in the arable lands was compared in long-unused plots that had been removed from the arable lands several decades ago (territories of cemeteries, parks, outskirts of villages, etc.)

The data from dozens of points were processed, which ensures the reliability of the data. The depth of $50 \mathrm{~cm}$ covers the $\mathrm{A}$ and $\mathrm{AB}$ horizons, i.e., the most root-inhabited layer.

Table 2 shows that the density of ordinary black soil (carbonate) of the steppe agricultural lands in arable land is slightly higher. The average density of typical black soil highly leached from carbonates is $1.32 \mathrm{~g} / \mathrm{cm}^{3}$, which is on the verge of being acceptable to cultivated plants. 
Table 2. The current state of soils of the Krasnodar region (the data from KubanNIIgiprozem, 2014)

\begin{tabular}{|c|c|c|c|c|}
\hline Agricultural land and soil name & Grounds & $\begin{array}{c}\text { Soil density in the } \\
0-50 \mathrm{~cm} \text { layer, } \mathrm{g} / \mathrm{cm}^{3}\end{array}$ & $\begin{array}{l}\text { The average content } \\
\text { of humus in the } \\
0-50 \mathrm{~cm} \text { layer, } \mathrm{t} / \mathrm{ha}\end{array}$ & $\begin{array}{l}\text { Humus reserves in } \\
\text { the fertile layer, } t / \text { ha }\end{array}$ \\
\hline \multirow{2}{*}{$\begin{array}{l}\text { Lowland steppe arid ordinary } \\
\text { very thick light-loamy black soil }\end{array}$} & Fallow & 1.25 & 3.94 & 621.3 \\
\hline & Arable land & 1.28 & 2.94 & 576.8 \\
\hline \multirow{2}{*}{$\begin{array}{l}\text { Lowland-depression meadow- } \\
\text { steppe Typical ultra-thick light } \\
\text { loamy }\end{array}$} & Fallow & 1.25 & 3.8 & 761.6 \\
\hline & Arable land & 1.32 & 3.0 & 597.7 \\
\hline
\end{tabular}

A decreased humus content in the upper horizons and an overall decrease in the humus content are observed in the same soils. The tendency to decreasing the humus content is confirmed by the data of the fixed-route surveys along the paths of the pioneers (Table 3 ). Over more than a century of intensive development of the West Ciscaucasia steppes, the content of humus in the soil has decreased by $25-30 \%$. In the early 20 th century, these soils were characterized as low humic (the humus content in the A-horizon was $4-5 \%$ ); currently, these soils have become slightly humic (less than $4 \%$ of humus) [Vlasenko, Terpelets, 2012; Sobol et al., 2017; Bakharev et al. 2018].

\section{The existing and promising approaches to the development of agricultural systems}

An important element of a farming system is the structure of sown areas (Table 4). The analysis of the structure of the sown areas in agricultural organizations of the Krasnodar Krai for 2000-2016 showed that the area of all crops had reduced by 518.2 thousand ha, or by $17.3 \%$, while the share of grain crops had increased from 53.1 to $65.4 \%$ with a simultaneous increase of the sugar beet and sunflower crops (Table 4).
In the Krasnodar Krai, the production of sugar beet and sunflower is efficient - the net income from one ha is 24 and 18 thousand rubles, and the profitability level is 45 and $76 \%$, respectively.

The problem is the reduction in the sown area of perennial and annual herbs; currently, their share in the cropping pattern is less than $6 \%$. The area of fodder and leguminous crops decreased. This can be explained by a significant decrease in the cattle population in the Krasnodar Krai and a reduction in the need for green and coarse feeds.

The existing structure of the sown areas cannot be considered optimal; the change is aimed at generating profit; there is no differentiation by the natural landscapes of the region.

The perennial and annual herbs are the best predecessors of basic crops, which provide a positive balance of humus, and stabilize the natural potential of cultivated lands.

The Farming Systems in the Krasnodar Krai (Recommendations) methodological recommendations regularly developed by scientific research organizations [The farming system in the Krasnodar Krai, 2015; Koshchaev et al., 2018] traditionally offer the measures for implementing the agricultural systems differentiated for seven natural and economic zones of the region. However,

Table 3. Changes in the content of humus in the arable layer of the steppe lands over the century [Vlasenko, Achkanov, 2014]

\begin{tabular}{|c|c|c|c|}
\hline \multirow{2}{*}{ Author, year of research } & \multirow{2}{*}{ Sampling location } & \multicolumn{2}{|c|}{ Humus content, \% } \\
\hline & & at the moment of the study & at present \\
\hline \multicolumn{4}{|l|}{ Ordinary clack soil } \\
\hline P. A. Solomin, 1890 & st.Kushchevskaya & 5.4 & 3.8 \\
\hline K. S. Kirichenko, 1953 & st.Novokubanskaya & 4.8 & 3.8 \\
\hline \multicolumn{4}{|l|}{ Typical black soil } \\
\hline V.V. Dokuchaev, 1875 & st.Ladozhskaya & 4.6 & 3.7 \\
\hline V.V. Dokuchaev, 1875 & st.Redutskaya & 4.9 & 3.5 \\
\hline V.V. Dokuchaev, 1875 & st.Tbilisskaya & 5.1 & 4.1 \\
\hline S. A. Yakovlev, 1914 & Armavir & 4.5 & 3.5 \\
\hline \multicolumn{4}{|l|}{ Leached black soil } \\
\hline V.V. Dokuchaev, 1875 & Ekaterinodar & 5.0 & 3.0 \\
\hline V.V. Dokuchaev, 1875 & st.Kushevskaya & 5.7 & 3.7 \\
\hline
\end{tabular}


Table 4. The structure of crops sown areas in agricultural companies of the Krasnodar Krai*

\begin{tabular}{|l|c|c|c|c|c|c|c|c|}
\hline \multirow{2}{*}{ Indicator } & \multicolumn{2}{|c|}{$\begin{array}{c}\text { On average } \\
\text { for 2000-2004 }\end{array}$} & \multicolumn{2}{c|}{$\begin{array}{c}\text { On average } \\
\text { for 2005 - 2009 }\end{array}$} & \multicolumn{2}{c|}{$\begin{array}{c}\text { On average } \\
\text { over 2010 - 2014 }\end{array}$} & \multicolumn{2}{c|}{$\begin{array}{c}\text { On average } \\
\text { for 2015-2016 }\end{array}$} \\
\cline { 2 - 10 } & thous. ha & $\begin{array}{c}\% \text { of the } \\
\text { total }\end{array}$ & thous. ha & $\begin{array}{c}\% \text { of the } \\
\text { total }\end{array}$ & thous. ha & $\begin{array}{c}\% \text { of the } \\
\text { total }\end{array}$ & thous. ha & $\begin{array}{c}\% \text { of the } \\
\text { total }\end{array}$ \\
\hline $\begin{array}{l}\text { Grains and } \\
\text { legumes - total }\end{array}$ & $1,593.4$ & 53.1 & $1,550.5$ & 57.7 & $1,552.9$ & 61.0 & $1,622.4$ & 65.4 \\
\hline $\begin{array}{l}\text { including winter } \\
\text { wheat }\end{array}$ & 907.8 & 30.3 & 908.7 & 33.8 & 940.3 & 36.9 & $1,016.1$ & 40.9 \\
\hline rice & 103.9 & 3.5 & 110.8 & 4.1 & 121.7 & 4.8 & 124.6 & 5.0 \\
\hline maize for grain & 130.4 & 4.3 & 245.5 & 9.1 & 314.7 & 12.4 & 330.6 & 13.3 \\
\hline beans and legumes & 59.4 & 2.0 & 30.9 & 1.2 & 26.4 & 1.0 & 24.9 & 1.0 \\
\hline $\begin{array}{l}\text { Commercial crops } \\
\text { - total }\end{array}$ & 515.5 & 17.2 & 595.2 & 22.2 & 612.9 & 24.1 & 577.0 & 23.3 \\
\hline $\begin{array}{l}\text { including sugar } \\
\text { beet }\end{array}$ & 126.8 & 4.2 & 129.2 & 4.8 & 151.0 & 5.9 & 148.2 & 6.0 \\
\hline sunflower & 308.9 & 10.3 & 334.2 & 12.4 & 304.8 & 12.0 & 276.7 & 11.2 \\
\hline soybeans & 59.1 & 2.0 & 104.9 & 3.9 & 119.4 & 4.7 & 127.6 & 5.1 \\
\hline $\begin{array}{l}\text { Potatoes and } \\
\text { melons - total }\end{array}$ & 29.7 & 1.0 & 24.3 & 0.9 & 23.8 & 0.9 & 23.1 & 0.9 \\
\hline $\begin{array}{l}\text { Fodder crops - } \\
\text { total }\end{array}$ & 861.2 & 28.7 & 516.8 & 19.2 & 357.6 & 14.0 & 259.1 & 10.4 \\
\hline $\begin{array}{l}\text { including annual } \\
\text { herbs }\end{array}$ & 203.0 & 6.8 & 104.2 & 3.9 & 71.4 & 2.8 & 40.5 & 1.6 \\
\hline perennial herbs & 268.3 & 8.9 & 174.5 & 6.5 & 125.4 & 4.9 & 103.5 & 4.2 \\
\hline Sown area - total & $2,999.8$ & 100 & $2,686.8$ & 100 & $2,547.2$ & 100 & $2,481.6$ & 100 \\
\hline
\end{tabular}

*The information of the territorial body of the Federal State Statistics Service for the Krasnodar Krai

they do not consider the peculiarities of natural landscapes, the types of degradation processes, and the degrees of their manifestation within the landscapes.

The boundaries of cultivated lands seldom coincide with the boundaries of the natural and economic zones of the region. In this regard, in the opinion of the authors, it is necessary to review the approach to establishing the boundaries of the zones following the existing system for assessing the production value of the soils (the ball-bonitet, the grain equivalent, etc.) [Barsukova et al., 2015; Vlasenko, Terpelets, 2008;Ratoshny et al., 2018].

The essence of the adaptive-landscape farming systems is in maximizing the use of all the natural factors for yield formation: the terrain, the soil, the water, the climate, and utmost adaptation of the crops and technologies of their cultivation to the characteristics of each landscape [Barsukova et al., 2015;Achkanov, Vasilko, 2006;Anisimova et al., 2018].

\section{RESULTS}

The use of the GIS technologies allowed identifying the regularities of increasing the areas of waterlogged soils in various types of cultivated lands, which are as follows:
- in the lowland-depression cultivated land with numerous depressive forms of meso- and microrelief, an increase in the area of water-saturated soils (lands) is associated with an expansion of the area of the existing depressions and the appearance of new ones;

- in the plain-erosive cultivated land with weakly expressed erosive terrain, the development of prairiefication occurs in the watershed spaces, where the slopes are the smallest - in ravine tributaries.

Having an extensive catchment, even with a clear deficit of moisture, the bottoms of depressions are waterlogged. Under the influence of heavy tillage equipment operating on highly humidified soils and, especially, as a result of the formation of the plow sole, the depressed area has more than doubled over the observation period.

Over the long period of intensive development of the West Ciscaucasia steppes, the content of humus in the soil has decreased by $25-30 \%$. The soils that were low humic at the beginning of the 20th century have currently become slightly humic.

Following the classification adopted in the Soil and Environmental Atlas of the Krasnodar Krai, with the use of GIS technology (MapInfo program), the authors determined the boundaries 
of the five natural landscapes in the Krasnodar Krai and characterized their climatic and soil characteristics.

For example, Table 5 shows the climatic, the soil, and the ecological characteristics of the plain-lowland landscape with plowed steppes [Barsukova, Derevenetz, 2016; Nechaev et al., 2016; Troshin et al., 2018]. All types of erosion, as well as water-saturated agricultural lands (arable land) can be found within the boundaries of the natural landscape. The percentage of the areas with the manifestations of negative processes has been determined - weak and medium wind erosion, strong wind erosion, and weak and medium water erosion; weak and medium water erosion and weak, medium wind erosion; severe water erosion and water-saturated arable land.

In the studies, the percentage ratio "arable land:meadow:forest" on the example of the natural plain-lowland landscape with plowed steppes was determined as 73:3:6. The eco-landscape approach involves finding such a ratio of the area of arable land, pastures, hayfields, forests, nature reserves, villages, settlements, and other anthropogenic and environment-stabilizing lands that would ensure the self-regulation of the cultivated land.

The authors performed an eco-economic assessment of the field crop rotations with a set of crops that ensured diversified development of crop breeding, as recommended by the Farming Systems 2015 document in force for the Central Zone of the Krasnodar Krai. The authors adapted the crop rotations to the natural landscape by cultivated lands. The field crop rotations developed with the consideration of the features of the landscape will ensure, per one ha of arable land, the annual gross output value of 32.3-37.0 thousand rubles, the net income of 11.5-12.9 thousand rubles, and the profitability level of $52.4-55.4 \%$. The calculations were made in the prices and cost of production for 2015 .

A preliminary calculation of the amount of mineralized or grown humus was made, which was based on the predicted crop yield and ratio of the alienated to the remaining part of the biomass. The designed crop rotations ensure a positive balance of humus and an optimal cropping pattern [Barsukova, Derevenetz, 2016; Nechaev et al., 2016; Zhuchenko, 2011].

Table 5. Climatic, soil, and ecological peculiarities of the natural landscape I (plain-lowland landscape with plowed steppes)

\begin{tabular}{|c|c|}
\hline Indicators & Values \\
\hline Total landscape area, thous. ha & 580.6 \\
\hline including agricultural lands & 467.8 \\
\hline of these, arable land & 425.9 \\
\hline perennial plantings & 7.8 \\
\hline hayfields & 9.5 \\
\hline pastures & 24.6 \\
\hline Forests & 1.7 \\
\hline of these, forest bands & 13.3 \\
\hline The ratio of lands, $\%$ arable land:meadows:forests & 73:3:6 \\
\hline Index of plowness (Ip) & 0.73 \\
\hline The index of area woodiness (Iwood) & 0.06 \\
\hline The average annual rainfall, $\mathrm{mm}$ & 478 \\
\hline Humidification coefficient & 0.26 \\
\hline The sum of effective temperatures, ${ }^{\circ} \mathrm{C}$ & 3475 \\
\hline The content of humus in the A horizon, $\%$ & $3.5-4.0$ \\
\hline The thickness of the humus layer, $\mathrm{cm}$ & $80-133$ \\
\hline Prevailing soils & $\begin{array}{l}\text { Ordinary slightly humic thick and extra-thick black soils. } \\
\text { Meadow-black soil, including compacted soil. Meadow } \\
\text { solodized soil and alkalized soil occur sometimes }\end{array}$ \\
\hline $\begin{array}{l}\text { Negative processes, \%: } \\
\text { weak and moderate wind erosion }\end{array}$ & 72.2 \\
\hline strong wind erosion and weak and medium water erosion & 0.6 \\
\hline very strong wind erosion & - \\
\hline $\begin{array}{l}\text { mild and moderate water erosion and mild and moderate } \\
\text { wind erosion }\end{array}$ & 11.9 \\
\hline strong water erosion & 1.6 \\
\hline Water-saturated arable land & 13.7 \\
\hline
\end{tabular}




\section{CONCLUSION}

1. The changes in the geomorphological appearance of cultivated lands in Western Ciscaucasia consist of the formation of windborne hillocks along or inside forest belts and the increasing areas of secluded depressions. The windborne hillocks crossing the sloughs of the gill network resulted in a local blocking of the surface and subsurface runoff and the formation of new secluded depressions. The physical degradation of the land, intensive loss of humus, and development of water saturation and waterlogging of arable land were noted.

2. The analysis of the structure of the agricultural lands shows a very high degree of plowness of the steppe cultivated land, the extremely low share of environment-stabilizing components forest and bushes, water control and forest shelter belts, hayfields and pastures, and micronurseries required for creating the ecological framework for a sustainably cultivated land.

3. Within the boundaries of each natural landscape, in the context of cultivated land, one should design scientifically substantiated crop rotations adapted for natural landscapes and cultivated lands and ensuring an optimal cropping pattern and the maximum net income under the conditions of preserving soil fertility.

4. Within the boundaries of landscapes, it is necessary to design the agricultural complexes of anti-erosion measures differentiated by natural landscapes and cultivated lands, taking into account the types and the degree of the manifestation of the erosion processes.

5. A conclusion indicating the need for further research for clarifying the methodology of designing adaptive landscape farming systems with regard to the natural and economic peculiarities of the Krasnodar Krai was drawn.

\section{REFERENCES}

1. Achkanov A.Y., Vasilko V.P. 2006. Landshaftnoekologicheskoe zemledelie yuga Rossii [Landscape-ecological farming in the South of Russia]. Krasnodar: KubSAU.

2. Agroekologicheskii monitoring v zemledelii Krasnodarskogo kraya [Agroecological monitoring in the agriculture of the Krasnodar Krai]. 1997. Anniversary issue. Krasnodar: KSAU, 236.

3. Anisimova E.I., Koshchaev A.G., Nesterenko A.A., Bakharev A.A., Isaeva A.G., Shuvaeva T.M.,
Kalashnikova T.V. 2018. Comparative Assessment of The Relationship Between Intrabreed Types of Simmental Cows and Sectionized Traits. International Journal of Pharmaceutical Research, 10(4), 604-610.

4. Bakharev A.A., Sheveleva O.M., Fomintsev K.A., Grigoryev K.N., Koshchaev A.G., Amerkhanov K.A., Dunin I.M. 2018. Biotechnological characteristics of meat cattle breeds in the Tyumen region. Journal of Pharmaceutical Sciences and Research, 10(9), 2383-2390.

5. Barsukova G.N., Bershitsky Y.I., Nechaev V.I. 2015. Kontseptsiya adaptivno-landshaftnoi organizatsii territorii selkhozpredpriyatii [The concept of adaptive landscape organization of the territory of agricultural enterprises]. AIC: Economy, management, 2, 19-27.

6. Barsukova G.N., Derevenetz D.K. 2016. Ekologolandshaftnyi podkhod $\mathrm{k}$ organizatsii selskokhozyaistvennogo proizvodstva kak uslovie resheniya problemy prodovolstvennoi bezopasnosti [The ecolandscape approach to the organization of agricultural production as a prerequisite for resolving the problem of food security]. Polythematic network electronic scientific journal of the Kuban State Agrarian University, 115, 1155-1169.

7. Barsukova G.N., Zhukov V.D., Radchevsky N.M. 2015. Ekologo-landshaftnyi podkhod k organizatsii territorii selskokhozyaistvennykh predpriyatii [The eco-landscape approach to the organization of the territory of agricultural enterprises]. Proceedings of the Kuban State Agrarian University, 1 (52), 19-27.

8. Garkovenko A.V., Radchenko V.V., Ilnitskaya E.V., Koshchaev A.G., Shchukina I.V., Bakharev A.A., Sukhanova S.F. 2018. Polymorphism of cattle microsatellite complexes. Journal of Pharmaceutical Sciences and Research, 10(6), 1545-1551.

9. Kiryushin V.I. (Ed.) 2005. Agroekologicheskaya otsenka zemel, proektirovanie adaptivno-landshaftnykh sistem zemledeliya i agrotekhnologii [Agroecological assessment of lands, designing adaptive-landscape farming systems and agricultural technologies]. Methodological guide. Moscow: Federal State Scientific Institution "Rosinformgrotech".

10. Koba I.S., Lysenko A.A., Koshchaev A.G., Shantyz A.K., Donnik I.M., Dorozhkin V.I., Shabunin S.V. 2018. Prevention of Mastitis in Dairy Cows on Industrial Farms. Journal of Pharmaceutical Sciences and Research, 10(10), 2582-2585.

11. Koshchaev A.G., Lysenko Y.A., Luneva A.V., Gneush A.N., Aniskina M.V., Fisinin V.I., Saleeva I.P. 2018. Studying Biological Activity of Lactobacillus Hydrolysates. Journal of Pharmaceutical Sciences and Research, 10(10), 2475-2479.

12. Koshchaev A.G., Lysenko Y.A., Semenenko M.P., Kuzminova E.V., Egorov I.A., Javadov E.J. 2018. Engineering and development of probiotics for 
poultry industry. Asian Journal of Pharmaceutics, 12(4), S1179-S1185.

13. Koshchaev A.G., Shchukina I.V., Garkovenko A.V., Ilnitskaya E.V., Radchenko V.V., Bakharev A.A., Khrabrova L.A. 2018. Allelic variation of marker genes of hereditary diseases and economically important traits in dairy breeding cattle population. Journal of Pharmaceutical Sciences and Research, 10(6), 1566-1572.

14. Koshchaev A.G., Lysenko Y.A., Lysenko A.A., Luneva A.V., Saleeva I.P., Fisinin V.I. 2017. Screening of microorganism symbiont strains as a base of probiotics for poultry industry. Journal of Pharmaceutical Sciences and Research, 9(8), 1373-1379.

15. Kryukov N.I., Yurchenko V.O., Koshchaev A.G., Gorkovenko N.E., Vinokurova D.P., Bogosyan A.A., Sukhanova S.F. 2018. The Derivative Of Prussian Blue Paint - Khzh-90 Cesium Isotopes' Sorbent At Mycotoxicoses. International Journal of Pharmaceutical Research, 10(4), 669-674.

16. Marchenko Z.S., Vlasenko V.P., Bondar A.V., Suetina G.M. et al. 2008. Analiticheskaya zapiska ob ispolzovanii i sostoyanii zemel na territorii Krasnodarskogo kraya [An analytical note on the use and the state of land in the Krasnodar Krai]. FSUE "Goszemkadastrsyomka" - the All-Russia Institute of Agricultural and Aerial Photo Geodesic Surveys (VISHAGI). Krasnodar, 78 p.

17. Nechaev V., Barsukova G., Saifetdinova N., Derevenets D. 2016. Innovative and environmental aspects of switching to the adaptive-landscape system of agriculture. AIC: Economics, Management, 11, 30-14.

18. Ratoshny A.N., Soldatov A.A., Kononenko S.I., Tuzov I.N., Koshchaev A.G. 2018. Organization of feeding dairy cows for preventing metabolic disorders. Journal of Pharmaceutical Sciences and Research, 10(12), 3273-3276.

19. Saleeva1 I.P., Lukashenko V.S., Koshchaev A.G., Volik V.G., Ismailova D.Y. 2018. Quality of Broiler Chicken Meat with the Use of Various Methods of Growing. Journal of Pharmaceutical Sciences and Research, 10(11), 2979-2984.

20. Serdyuchenko I.V., Koshchaev A.G., Guguchvili N.N., Zholobova I.S., Donnik I.M., Smirnov A.M., Usha B.V. 2018.Microbiocenosis of the intestinal tract of honeybees and its correction. OnLine Journal of Biological Sciences, 18(1), 74-83.

21. Sistema zemledeliya Krasnodarskogo kraya [The farming system in the Krasnodar Krai]: methodical recommendations - Krasnodar, 2015, 265 p.

22. Skvortsova L.N., Koshchaev A.G., Shcherbatov V.I., Lysenko Y.A., Fisinin V.I., Saleeva I.P., Sukhanova S.F. 2018. The use of probiotics for improving the biological potential of broiler chickens. International Journal of Pharmaceutical Research, 10(4), 760-765.
23. Sobol I.V., Donchenko L.V., Rodionova L.Y., Koshchaev A.G., Stepovoy A.V. 2017. Peculiarities of analytical characteristics of pectins extracted from sunflower hearts. Asian Journal of Pharmaceutics, 11(1), S97-S100.

24. Troshin A.N., Onischuk P.D., Koshchaev A.G., Kudinova S.P., Koshchaeva O.V., Nikitin V.Y., Krivonogova A.S. 2018. Parameters of acute toxicity of the Ferro-Quin iron-sorbitol-protein complex. International Journal of Pharmaceutical Research, 10(4), 784-790.

25. Troshin A.N., Turchenko A.N., Onischuk P.D., Koshchaev A.G., Kudinova S.P., Shantyz A.Y., Koshchaeva O.V. 2018. Long-term use of iron-mineral and iron-organic drugs. International Journal of Pharmaceutical Research, 10(4), 791-797.

26. Tuzov I.N., Ryadchikov V.G., Ratoshniy A.N., Kulikova N.I., Koshchaev A.G. 2018. Using Holstein Cattle in Conditions of the Krasnodar Territory. Journal of Pharmaceutical Sciences and Research, 10(12), 3160-3163.

27. Vlasenko V. P., Achkanov A. Y. 2014. Vliyanie prirodnykh i antropogennykh faktorov na sostoyanie pochvennogo pokrova Zapadnogo Predkavkazya [The effect of natural and anthropogenic factors on the state of the soil cover of Western Caucasus]. Proceedings of the Kuban State Agrarian University, 50, 3-28.

28. Vlasenko V.P., Terpelets V.I. 2008. Gidromorfnaya degradatsiya chernozemov Zapadnogo Predkavkazya [Hydromorphic degradation of black soils of Western Ciscaucasia] (a study guide). Krasnodar, the Kuban State Agrarian University, 206 p.

29. Vlasenko V.P., Terpelets V.I. 2012. Degradatsionnye protsessy v pochvakh Krasnodarskogo kraya i metody ikh regulirovaniya [Degradation processes in the soils of the Krasnodar Krai and the methods of their regulation] (monograph). Krasnodar, the Kuban SAU, 204 p.

30. Zhuchenko A.A. 2011. Osnovy perekhoda k adaptivnoi strategii ustoichivogo razvitiya APK Rossii [Bases for switching to the adaptive strategy of AIC sustainable development in Russia]. Economics of agricultural and processing enterprises, 8, 1-3.

31. Zhukov V.D., Sheujen Z.R. 2017. Vliyanie dinamiki agroklimaticheskikh faktorov na sostoyanie zemel selskokhozyaistvennogo naznacheniya v Krasnodarskom krae [The effect of the dynamics of agroclimatic factors on the state of agricultural lands in the Krasnodar Krai]. In the book: Socio-economic and legal foundations for the development of a modern society/Collective monograph. Penza, 80-88.

32. Zverzhanovskiy M.I., Zabashta S.N., Kataeva T.S., Koshchaev A.G., Nazarov M.V. 2017. Epizootic trichinellosis situation and consortive links in jackals (Canis aureus L.) in North-western Region of Russia. Indian Veterinary Journal, 94(10), 29-32. 